\title{
Examining the Antecedents of Job Satisfaction and further its impact on Organizational Commitment
}

\author{
Aisha Javeria \\ MS Scholar, Department of Business Administration \\ NCBA\&E, Bahwalpur, Pakistan \\ Muhammad Rizwan \\ Lecturer, Department of Management Sciences, \\ The Islamia University of Bahawalpur, Pakistan \\ Email: rizwan.arshad@iub.edu.pk
}

Ali Junaid khan

MS Scholar, Department of Business Administration NCBA\&E, Bahwalpur, Pakistan

Amjad Hameed

MS Scholar, Department of Business Administration NCBA\&E, Bahwalpur, Pakistan

\section{Qazi Naeem}

MS Scholar, Department of Business Administration NCBA\&E, Bahwalpur, Pakistan

Muhammad Subctageen

MS Scholar, Department of Business Administration NCBA\&E, Bahwalpur, Pakistan

Accepted: September 13, 2013 DOI: 10.5296/jpag.v3i3.6224 


\section{$\Lambda$ Macrothink}

\section{Abstract}

\section{Abstract}

The Human capital plays a vital role in success of any organization. The contended and committed employee is a key to achieve organizational objective. There are several researches conducted to understand the function of worker's satisfaction and commitment towards job but this area of study is remain unexposed. The purpose of this study is to discuss and examine the forces which lead to private and govt sector workers Job satisfaction and organizational commitment. A theoretical model was anticipated and tested and findings indicates various challenges for HRM that the factors which contributes to job satisfaction does not necessarily makes the employee committed. This research is a cross sectional study. A sample of 170 respondents was taken from the Public and Private sector Professional around Pakistan. The data was collected through a self-administered questionnaire, using the earlier conventional scales and the results demonstrated that Relationship with coworkers, workplace environment, empowerment, pay and promotion have a significant positive relationship with job satisfaction while in turn only the job satisfaction and empowerment leads to organizational commitment. Relationship with coworkers, pay and promotion and workplace environment have insignificant relation with organizational commitment.

Keywords: Organizational Commitment, Job satisfaction, Employee Empowerment, Work place environment, Pay \& Promotion, Relationship with Coworkers.

\section{Introduction}

The Human capital is the best ever investment of an organization, to keep them effective, efficient and retain with an organization, Job satisfaction and organizational commitment plays a vital role. The universal principle is that if the organization endow with structured policies, provide his employee the rational pay \& promotion, arrange best working places and encourage employee contribution toward work assignments the employee in turn give out their best performance and sizeable output.

The globalization radically restructures the organizational environment, therefore output is evident in term of Qualitative and quantitative attributes, the qualitative attributes highlights high Quality product \& Services and organizational performance. Consequently, Organizational performance creates stress over employee to give the best performance.

Therefore Personnel management such as Pay \& promotion, manager's appreciation and Job satisfaction are the great areas of concern by Organization (Willems et al., 2004).Organization applied various theories \& techniques in context of employee's job satisfaction, that create strong bonding between employee and organization (Horton, 2006).

The job satisfaction is a great area of concern by researcher of past several decades, researches have been conducted to analysis the role of job satisfaction in organizational commitment.

Job satisfaction is universally defined as employee's likeability towards work .Various aspects of job satisfaction, job contentment and relationship between job commitment and job 
satisfaction is widely discussed in past researches.

Researches show that Maslow's hierarchy of needs and motivation theory provides basis for job satisfaction. This theory proves that people looking for five types of basic need i.e need for physiological, safety, social, self esteem and self actualization .job satisfaction is also studied under demographic variables i.e gender ,race, age, education and professional experience .

The relationship between organizational commitment and job satisfaction shows that satisfied employee strongly associated with organization and evident organizational commitment (Kalleberg .1990)research on organization commitment and job satisfaction in USA and Japan found a correlation between job satisfaction and organization commitment .Personal management is an essential part of an organizational resources . Committed employees can help make an organization competitively more prestigious and profitable. The present study is an attempt to find out the major factors that contributes to the employee satisfaction and commitment.

\section{2-Literature review}

\section{1-Job Satisfaction}

Job satisfaction is still a charisma to explore more and a Pandora box which opens a several new variables associated with its roots as living parasites; however the extensive researches conducted on this topic in scientific as well as routine life, there is still no universal conformity for job satisfaction. There is such a broad range of explanation of job satisfaction is found in relationship with organizational commitment. Job satisfaction is defined in several studies in Different styles. When a person psychologically, environmentally and physiologically satisfied during course of his occupation he can be considered satisfied with his job. Hoppock (1935)

Job satisfaction is influenced by several external forces, but the internal contentment has significant effect over job satisfaction .it is a combination of several factors that is a root cause of job satisfaction. The influence of positive and negative feeling causes the job satisfaction of employee towards his assignment. The work attitude of employee signify job satisfaction place (Davis et al., 1985) (asad \& mudassar 2013).

\section{2-Organizational Commitment}

Job contentment or job satisfaction is a very important element of organizational commitment. Organizational commitment is significantly affected with job satisfaction. Resultantly, job satisfaction have positive influence over organizational commitment further employee who is more satisfied with job is more committed with his or her organization they are more willing to recognize their organizational values, work toward achievement of organizational objectives and consider their selves more responsible and accountable for the work assigned to them . (ulcer and usman 2010) 


\section{MInstitute Macrothink $^{\text {Int }}$}

$\mathrm{H}_{1}$ : There is a significant positive relationship between job satisfaction and organization commitment

\section{2-3.Empowerment}

The Process of decision making, take initiative to resolve the issues and sharing of concerned information with employee is falls in boundaries of empowerment and the idea behind employee motivation and increased productivity and performance, quality product $\&$ services and reduced turnover and higher Returns. (Lashley, 1995), explain by Bowen and Lawler in 1992 that it fuel trustworthiness and further describe by Mullins, 2005 that empowerment enhance utilization of employee acquaintance and expertise .In 2003,Pardo del Val and Lloyd stated that Besides all researches conducted there is no formal definition of empowerment exist however it is considered as managerial research element, it considered as HR practice by (Huselid et al., 1997), Quinn and Spreitzer, 1997 named it as awareness of worker ,to award employees with resources, expertise and motivate through authority and held responsible for results, and answerable for task assigned is fals in category of empowerment.

$\mathbf{H}_{2}$ : There is a significant positive relationship between employee empowerment and job satisfaction

$\mathbf{H}_{3}$ : There is a significant positive relationship between employee empowerment and Organizational Commitment.

\section{4-Workplace Environment}

Employee job satisfaction significantly persuade by work environment i.e ventilation illumination, larger, cleaner and enhanced work places, these factors greatly influenced since employee recognized the surrounding that gives more relieve and placate . (Ceylan, 1998).

The provisions of these facilities by organization enhance employee's job contentment and commitment toward organization. (Ali \& gulsen, 2011).

The placement of employee to perform his every day assignments, either field work or office tasks all are part of work place environment. The other ingredients of work place environment are clatter level, clean air, stimulant refreshment and the incentives like baby care.

The Work place environment positively or negatively effect on employee job satisfaction level, due to type of work place environment. If work place environment is good then it must create positive impact and performance of employee also increases, this shows that work place environment is directly associated with satisfaction of an employee. Better environment facilitate the employee to best carry out the tasks. A favorable environment leads to fruitful results. The high satisfaction level of an employee lowers the turnover Intention. (Dole and Schroeder, 2001). Carlopio (1996) declare that work place contentment directly associated with job satisfaction and inversely linked with worker's intention to leave and organizational commitment for future prospects Work place environment also influence perception emotions and job fulfillment (Zalesny et al., 1985; Ferguson and Weisman, 1986; Oldham and Fried, 1987) 


\section{Macrothink}

Journal of Public Administration and Governance ISSN 2161-7104 2013, Vol. 3, No. 3

$\mathbf{H}_{4}$ : There is a positive relationship between working environment and job satisfaction

H5: There is a positive relationship between working environment and organization commitment

\section{5-Pay \& Promotion}

Pay \& Promotion are the key elements associated with worker's satisfaction and commitment. Maurer (2001) explains Pay \& promotion as correlated with organizational achievement. Survey results of Kathawala, Moore and Elmuti (1990) showed that Pay \& promotion and Salary package is important factor that impact the motivation and success factor of salaried employee in automobile industry. Employee turnover remarkably controlled by rewards and compensation, (Brown et al 2008). It also motivates the organizational commitment of the employee, which in turn attract and retain the employee with the job (Zobal, 1998; Chiu et al., 2002; Moncarz et al., 2009). Cappelli and Sherer (1998) stated that for an employee, the wages of the co-worker are more important than his own. Clark and Oswald 1996 and others, Hammermesh (2001) found that the increment in the earning shocks have noteworthy effect on employee job satisfaction, although its effect is temporary.

H6: There is a significant positive relationship between reward \& recognition and job satisfaction

$\mathbf{H}_{7}$ : There is a significant positive relationship between reward \& recognition and organization commitment

\section{6-Relationship with Co-workers}

Supervisor and co-worker's support is likely to not only increase the transparency of the job but also signal care, concern and support. Thus, the contentment and commitment is likely to be enhanced.(Therese 2006) There are various mechanism of the job that are of vital importance for satisfaction. A numerous of work associated construct have been linked to satisfaction. Some of these behaviors include work substance; have power over of work and actual performed tasks, direct supervision, promotion opportunities, financial rewards, co-workers and working conditions (Churchill et al., 1974; Ronan, 1970; Futrell, 1979)

$\mathbf{H}_{8}$ : There is a significant positive relationship between relationship with coworkers and job satisfaction

H9: There is a significant positive relationship between relationship with coworkers and organization commitment 


\section{Ml Macrothink}

\section{Research Model}

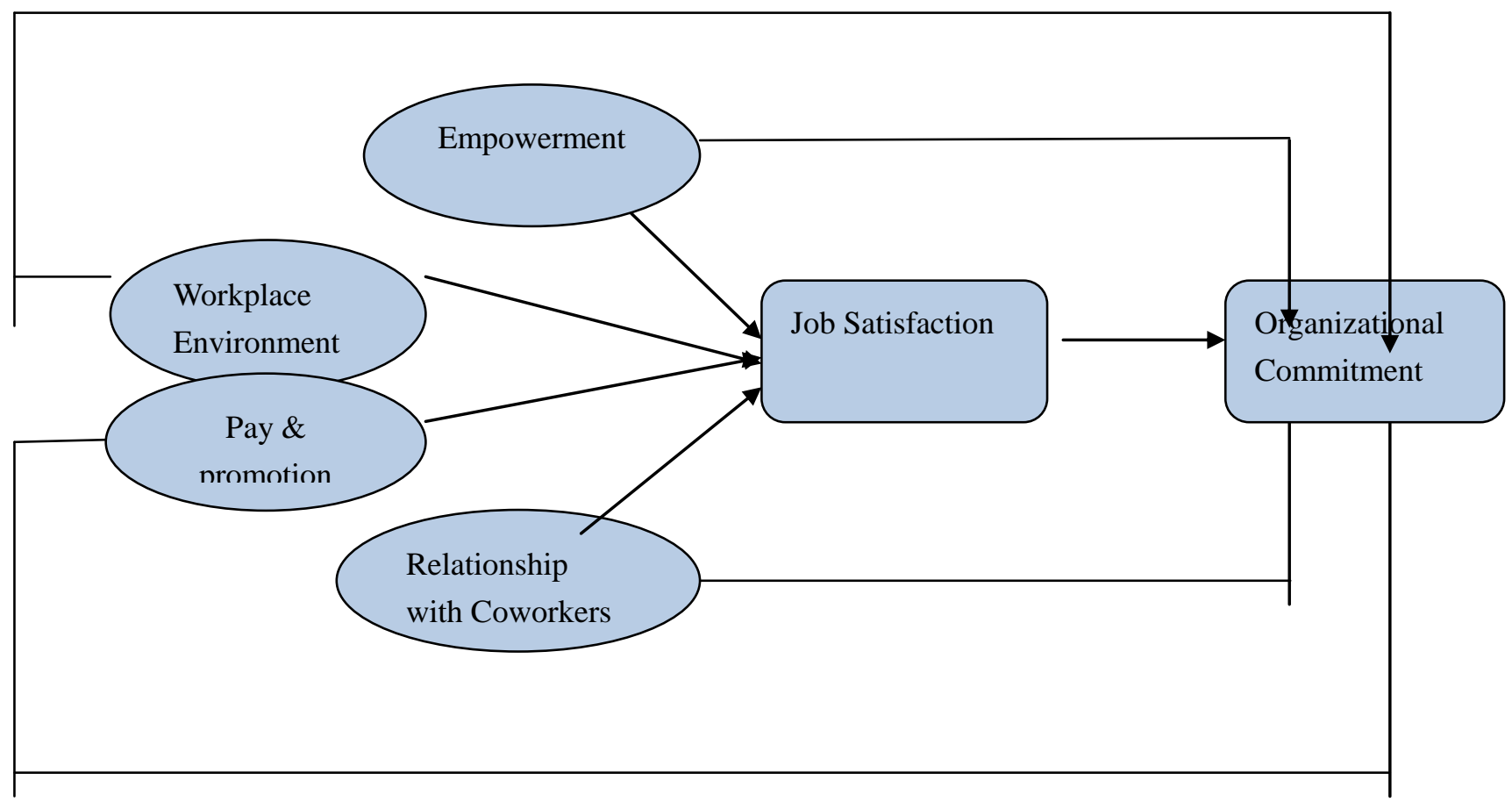

Fig 1 : Hypothetical Research Model

\section{3-Research Methodology}

The research examines the influence of pay \& promotion, working environment, relationship with coworkers, and empowerment organization commitment and Job satisfaction. The Statistics were collected from both public and private sector organizations that consist of a sample size of 170. The convenient sampling method was applied to gather the statistics from the desired population. Convenience sampling is a sampling technique that obtains and collects the relevant information from the sample or the unit of the study that are conveniently available (Zikmund, 1997). Convenience sampling is normally used for collecting a large number of completed surveys speedily and with Economy (Lym et al., 2010). The questionnaires were distributed via email and physical distribution and collect through same medium.

\section{1-Instrument and Measures}

Survey instrument of the current study address two major purposes: First is to analyze the relationship of various variables with organization commitment and job satisfaction. Second, to collect information about the different characteristics of the respondents that can be used to understand the variations in different categories.

The survey instrument contains two sections. Section 1 includes different personal and demographic variables. This section will obtain the respondent's information about gender, age, 
Income, education, job status and sector. Section 2 includes the latent variables that are important in the current study. The scales of the study were adopted from the previous literature and published studies. Of the 170 questionnaires distributed, 153 (90 percent) usable questionnaires were returned.

Table .1: Scale of Study

\begin{tabular}{|c|c|c|c|}
\hline No. & Variable & Items & References \\
\hline 1 & Empowerment & $\begin{array}{l}\text { 1. I am able to control the social contact with } \\
\text { others around me } \\
\text { 2. I have control over how I solve daily } \\
\text { problems } \\
\text { 3. I have the authority to correct daily problems } \\
\text { when they occur }\end{array}$ & $\begin{array}{l}\text { (Hackman and } \\
\text { Oldham, 1975) }\end{array}$ \\
\hline 2 & $\begin{array}{l}\text { Pay and } \\
\text { Promotion }\end{array}$ & $\begin{array}{l}\text { 1. I am satisfied with the existing salary } \\
\text { structure of the company. } \\
\text { 2. I am satisfied with the compensation I get } \\
\text { and I think it matches with my } \\
\text { responsibility. } \\
\text { 3. I am often rewarded for the quality of my } \\
\text { efforts. } \\
\text { 4. I am valued by my supervisor. }\end{array}$ & (Lee 2006) \\
\hline 3 & $\begin{array}{l}\text { Relationship } \\
\text { with } \\
\text { Coworkers }\end{array}$ & $\begin{array}{l}\text { 1. I am satisfied with work relationships with } \\
\text { the people around me. } \\
\text { 2. I am satisfied with various activities in the } \\
\text { firm \& love participating in them }\end{array}$ & $\begin{array}{l}\text { Kabir, M. M. } \\
(2011)\end{array}$ \\
\hline 4 & $\begin{array}{l}\text { Job } \\
\text { Satisfaction }\end{array}$ & $\begin{array}{l}\text { 1. Overall, I am pleased with my work } \\
\text { 2. My current work situation is not a major } \\
\text { source of frustration in my life } \\
\text { 3. If I had it to do it all over again, I'd still } \\
\text { choose to work where I do now }\end{array}$ & $\begin{array}{l}\text { Konrad et al. } \\
(1999)\end{array}$ \\
\hline 5 & $\begin{array}{l}\text { Organizational } \\
\text { Commitment }\end{array}$ & $\begin{array}{l}\text { 1. I would accept almost any type of job } \\
\text { assignment in order to keep working for this }\end{array}$ & $\begin{array}{l}\text { Mowday et al. } \\
\text { (1979) }\end{array}$ \\
\hline
\end{tabular}




\begin{tabular}{|c|c|c|c|}
\hline & & $\begin{array}{l}\text { organization } \\
\text { 2. I feel very much loyal to this organization } \\
\text { 3. I am proud to tell others that I am part of this } \\
\text { organization } \\
\text { 4. I talk up this organization to my friends as a } \\
\text { great organization to work for } \\
\text { 5. It would take very little chance in my present } \\
\text { circumstances to cause me to leave }\end{array}$ & \\
\hline 6 & Empowerment & $\begin{array}{l}\text { 4. I am able to control the social contact with } \\
\text { others around me } \\
\text { 5. I have control over how I solve daily } \\
\text { problems } \\
\text { 6. I have the authority to correct daily problems } \\
\text { when they occur }\end{array}$ & $\begin{array}{l}\text { (Hackman and } \\
\text { Oldham, 1975) }\end{array}$ \\
\hline 7 & $\begin{array}{l}\text { Workplace } \\
\text { Environment }\end{array}$ & $\begin{array}{l}\text { 1. My workplace provides an undisturbed } \\
\text { environment so that I can concentrate on } \\
\text { my work } \\
\text { 2. I am able to personalize my workspace } \\
\text { 3. My work area does not have many visual } \\
\text { distractions. }\end{array}$ & (Lee 2006) \\
\hline
\end{tabular}

\section{2-Procedure}

The questionnaire was distributed among 170 respondents in Bahawalpur. These respondents are selected based on the criteria above mentioned. Before giving the questionnaire, the purpose of study and questions were explained to the respondents so they can easily fill the questionnaire with relevant responses. A total of 153 questionnaires were selected and rest of the questionnaires was not included in the further analysis due to incomplete or invalid responses. After collecting the completed questionnaires, these questionnaires were coded and entered into SPSS sheet for further analysis.

\section{3-Reliability Analysis}

Reliability analysis confirms the internal consistency of the scales and Cronbach alpha values were obtained to check the reliability of the data. All the variables of the study were reliable as their cronbach alpha values were greater than the recommended value of 0.5 by Nanually (1996). and 0.60 by (Moss et al., 1998). 
Table 2. Reliability Analysis

\begin{tabular}{|l|l|l|}
\hline Scales & No of items & Chronbach alpha \\
\hline Empowerment & 3 & 0.567 \\
\hline Workplace environment & 3 & 0.625 \\
\hline Relationship with coworkers & 2 & 0.681 \\
\hline Pay and promotion & 4 & 0.651 \\
\hline Job satisfaction & 3 & 0.626 \\
\hline Organizational commitment & 5 & 0.771 \\
\hline
\end{tabular}

\section{Hypotheses Testing}

Table 3: Profile of the Respondents

Socio demographic characteristics of the participants are presented in the table given below

\begin{tabular}{|l|l|l|l|}
\hline Variable & Category & Frequency & Percentage \\
\hline Gender & Male & 85 & 55.6 \\
& Female & 68 & 44.4 \\
\hline Age & 20-25 years & 40 & 26.1 \\
25-30 years & 58 & 37.9 \\
30-35 years & 31 & 20.3 \\
35-40 years & 12 & 7.8 \\
above 40 years & 12 & 7.8 \\
\hline Income & below 15000 & 32 & 20.9 \\
& $15000-25000$ & 44 & 28.8 \\
& $26000-35000$ & 26 & 17.0 \\
$36000-45000$ & 22 & 14.4 \\
\hline
\end{tabular}




\section{Macrothink

\begin{tabular}{|l|l|l|l|}
\hline & above 45000 & 29 & 19.0 \\
\hline Education & Matriculation & 4 & 2.6 \\
& Inter & 12 & 7.8 \\
& Bachelors & 65 & 42.5 \\
& Master & 59 & 38.6 \\
& Mphil & 13 & 8.5 \\
\hline
\end{tabular}

\section{4-Result and Analysis}

\section{4-1- Job Satisfaction and Organizational Commitment}

According to the results of study job satisfaction has a significant positive relationship with organizational commitment with $(\beta=0.386)$ and $(\mathrm{p}<0.001)$ that means job satisfaction explains more than $38 \%$ variation in organizational commitment. Therefore $\mathrm{H} 1$ is accepted

\section{4-2. Empowerment, Job Satisfaction and Organizational Commitment}

The regression results shows that empowerment has significant positive relationship with both job satisfaction $(\beta=0.157)(\mathrm{p}<0.05)$ and organizational commitment $(\beta=0.255)(\mathrm{p}<$ 0.01). It means empowerment contributes $25 \%$ variation in organizational commitment and more than $15 \%$ in job satisfaction based on these results $\mathrm{H} 2$ and $\mathrm{H} 3$ are accepted.

\section{4-3. Workplace Environment, Job Satisfaction and Organizational Commitment}

Workplace environment has a significant positive relationship with job satisfaction $(\beta=$ 0.278 )

$(\mathrm{p}<0.001)$ while relationship with organizational commitment found to be insignificant $(\beta$ $=.079)(\mathrm{p}>0.05)$. The results confirm the acceptance of $\mathrm{H} 4$ and $\mathrm{H} 5$ is rejected.

\section{4-4.Pay and Promotion, Job satisfaction and Organizational Commitment}

Pay and promotion accounts for $13 \%$ variation in job satisfaction $(\beta=0.136)(\mathrm{p}<0.05)$ and have a significant positive relationship while it does not have significant effect on organizational commitment $(\beta=0.084)(\mathrm{p}>0.05)$ based on the results $\mathrm{H} 6$ is accepted and $\mathrm{H} 7$ is rejected. 


\section{Macrothink}

\section{4-5.Relationship with Co-workers, Job Satisfaction and Organizational Commitment}

Finally the results shows that relationship with coworkers have significant positive relation with job satisfaction and contributes more than $36 \%(\beta=0.364)(p<0.001)$ it contributes insignicantly in the relationship with organizational commitment $(\beta=0.088)(p>0.05)$.

\section{Table 4: Regression Result}

\begin{tabular}{|c|c|c|c|c|c|c|}
\hline Hypothesis & Model variables & Estimate & S.E & C.R & $\mathbf{P}$ & Results \\
\hline $\mathrm{H} 1$ & $\mathrm{JS} \longrightarrow \stackrel{\mathrm{OC}}{\longrightarrow}$ & 0.386 & 0.082 & 4.640 & $* * *$ & Supported \\
\hline $\mathrm{H} 2$ & Emp $\stackrel{\mathrm{JS}}{\longrightarrow}$ & .157 & 0.079 & 2.020 & 0.045 & Supported \\
\hline $\mathrm{H} 3$ & $\mathrm{Emp} \longrightarrow \quad \Theta C$ & .255 & 0.080 & 3.201 & 0.002 & Supported \\
\hline $\begin{array}{l}\mathrm{H} 4 \\
\mathrm{H} 5\end{array}$ & $\begin{array}{l}\mathrm{WPE} \longrightarrow \\
\mathrm{JS} \\
\mathrm{WPE} \longrightarrow \\
\mathrm{OC}\end{array}$ & $\begin{array}{l}.278 \\
.079\end{array}$ & $\begin{array}{l}0.071 \\
0.074\end{array}$ & $\begin{array}{l}3.795 \\
1.013\end{array}$ & $\begin{array}{l}* * * \\
0.313\end{array}$ & $\begin{array}{l}\text { Supported } \\
\text { Not Supported }\end{array}$ \\
\hline $\begin{array}{l}\text { H6 } \\
\text { H7 }\end{array}$ & $\begin{array}{l}\mathrm{P} \& \mathrm{P} \\
\mathrm{JS} \\
\mathrm{P} \& \mathrm{P} \longrightarrow \\
\mathrm{OC}\end{array}$ & $\begin{array}{l}.136 \\
.084\end{array}$ & $\begin{array}{l}0.045 \\
0.046\end{array}$ & $\begin{array}{l}2.262 \\
1.363\end{array}$ & $\begin{array}{l}0.025 \\
0.175\end{array}$ & $\begin{array}{l}\text { Supported } \\
\text { Not Supported }\end{array}$ \\
\hline $\begin{array}{l}\text { H8 } \\
\text { H9 }\end{array}$ & $\begin{array}{l}\mathrm{RCO} \longrightarrow \\
\mathrm{JS} \\
\mathrm{RCO} \longrightarrow \\
\mathrm{OC}\end{array}$ & $\begin{array}{l}.364 \\
.088\end{array}$ & $\begin{array}{l}0.064 \\
0.070\end{array}$ & $\begin{array}{l}5.136 \\
1.125\end{array}$ & $\begin{array}{l}* * * \\
0.263\end{array}$ & $\begin{array}{l}\text { Supported } \\
\text { Not Supported }\end{array}$ \\
\hline
\end{tabular}


H5 $(\beta=0.079)$

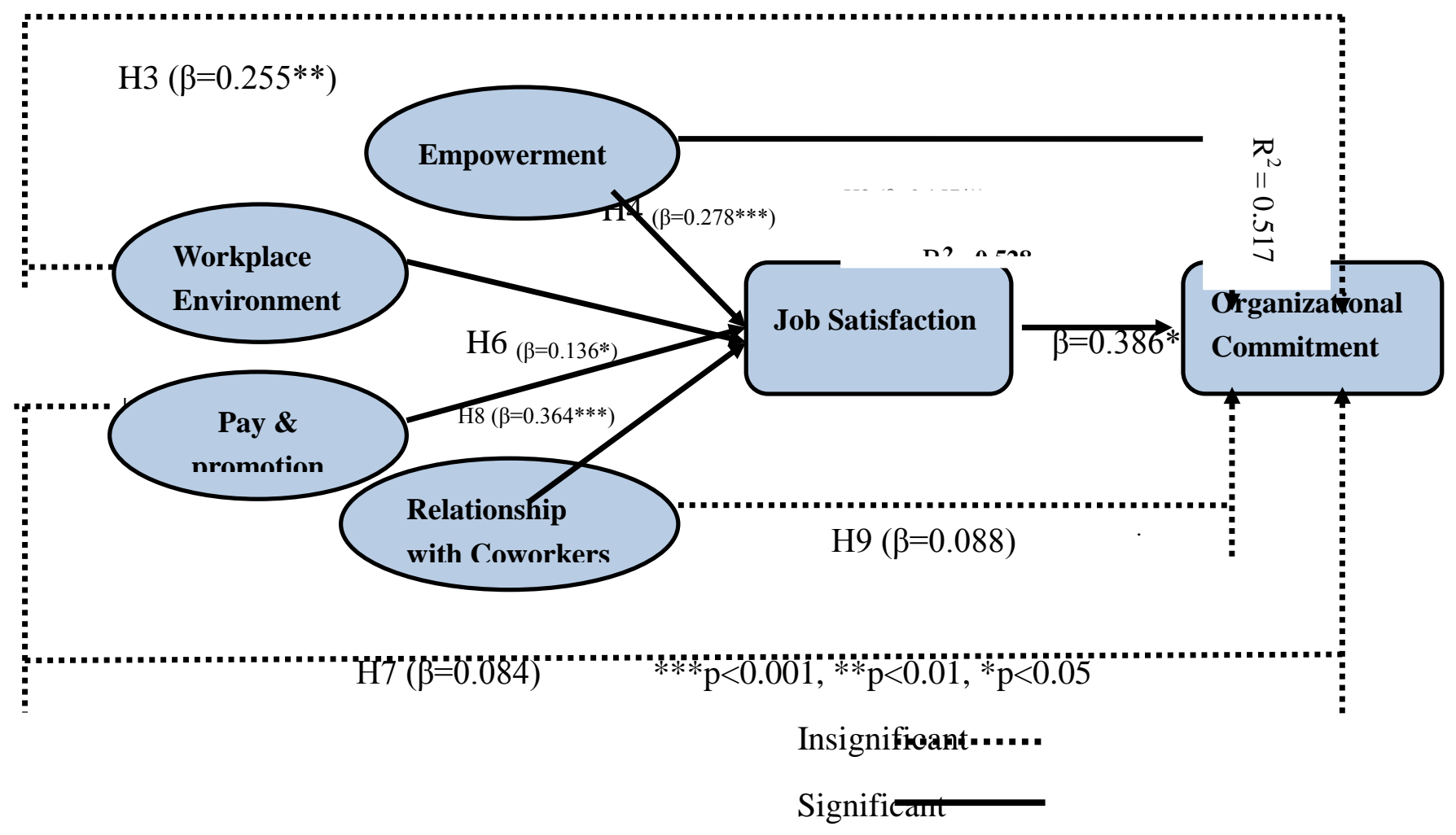

Figure 2: Structural Model Results

\section{5-Discussion and Managerial Implications}

The underlying principle of the Research work is to examine the dynamics behind any worker Satisfaction and its impact on organizational commitment in the govt and private sector of Pakistan. Important factors that affect job satisfaction are empowerment, workplace environment, pay and promotion and relationship with coworkers. In this study, workplace environment and relationship with coworkers were found to be the most important factors on workers Job satisfaction is usually subjective with quality of atmosphere where they have to complete their job assignments.

Secondly, whether function is performed bodily or maybe mental, it is carried out at the surroundings that have both corporal and communal consideration. The proper lighting, appropriate temperature and easy to use equipment are including in Workplace. The worker usefulness can be enhancing by providing entirely new work process. Also, top management should make available work spots which usually increase employee's health, comfort, ease, and welfare and maintain work assignments, when employees are flexible enough to learn and welcome to new processes. Well structured job also boost the conversation and cooperation between workers and divisions. 


\section{$\triangle$ Macrothink}

Third important result is consistent with previous research of Jun et al. (2006) and Maurer (2001) that Pay and promotion has a significant impact on employee satisfaction. Companies must develop proper pay and promotion system to promote employee involvement, in addition to support teamwork. To be able to attain the TQM implementation in an organization the processes and procedures should be restructured up to the standards. The Incentive policy of an organization should be recognizing the practices where employees are generally awarded. Output oriented awards should be organized.

According to Chao et al. (1994) Empowerment is very important factor that associated with workers satisfaction, Snipes et al. (2005). Being empowered requires the lowest level management to be engaged in decision making process with greater authority to correct the work related issues within the workplace. Past Researches showed that employees must be motivated to talk about reports, procedures and practices. Although organizations welcome the employee proposals, allow mutual discussion and organize conferences all are ineffective without empowering employee. The execution of prosperous administration is impossible without participation of employee. The restructuring of any organization should be done in a way that allow conservative to participative operational culture that welcomes the empowerment.

Finally the results indicate that only the job satisfaction and empowerment have significant relationship with organizational commitment while the workplace environment, relationship with coworkers and pay and promotion have insignificant relationship with commitment. This means it is more likely that the satisfied employees are also committed to the organization. Manager and leaders in organization should empower their employees and focus on the ways to increase the satisfaction which ultimately leads to the commitment towards organization.

\section{6-Conclusion}

The Research was carried out to investigate the antecedents of job satisfaction and their impact on the Employee commitment. Resultantly, research proves that variables of job satisfaction such as empowerment, workplace environment, relation with coworkers and pay $\&$ promotion significantly affect the level of job satisfaction. The research proves that there is a significant positive correlation between employee job satisfaction and organizational commitment.

The research indicate that if organization want to increase the satisfaction of their employees than importance should be given to empowerment, workplace environment, relationship with coworkers and pay \& promotion as all these variables are significantly related to job satisfaction while on the other hand only empowerment and job satisfaction leads to the commitment. Empowerment is the only variable which has positive significant correlation with both organizational commitment and job satisfaction, while Relationship with coworkers, workplace environment and pay \& promotion does not have significant impact on the commitment of employees. Our results have several implications for HRM and suggest that the pay and promotion is not the only factor which leads to employee satisfaction it can only satisfy the short term needs but in the long run to retain the skilled employees the 
organizations should go beyond the traditional practices.

\section{7-Limitations and Future Research}

The Research work experienced certain limitations because of resources and time restrictions. Very first constraint is usually the data is cross sectional in nature and does not allow the analysis over the different points in time. Secondly, number of respondents is very limited. Small sample furthermore restrict the power of the results of the regression analyses and therefore, the generalize ability of our results.

Thirdly, because very few antecedents to study the Job satisfaction and organizational commitment. Different factors needs to be included with different correlations along with other employee personal characteristic to understand employee job satisfactions and commitment. This Research did not consider the mediating role of job satisfaction and we take the organizational commitment as a whole while previous studies indicates the various types of organization commitment are important therefore future research can focus on measuring the impact of all these variable on different types of commitment separately.

\section{References}

Ahsan, N., Abdullah, Z., Fie, D.Y.G. and Alam, S.S. (2009), “A study of job stress on job satisfaction among university staff in Malaysia: empirical study", European Journal of Social Sciences, Vol. 8 No. 1, pp. 121-31.

Alamdar, H.K., Muhammad, M.N., Muhammad, A., and Wasim, H. (2011), "Impact of job satisfaction on employee performance: An empirical study of autonomous Medical Institutions of Pakistan"

Ali, T., Gulsen, A., Coskun, O., and Zbigniew, P. (2011), "Empirical study of public sector employee loyalty and satisfaction", Industrial Management \& Data Systems, Vol. 111 Iss: 5 pp. $675-696$.

Anastasios, P., Panagiotis, P., and Leda, P. (2011), "Organizational justice and employee satisfaction in performance appraisal", Journal of European Industrial Training, Vol. 35 Iss: 8 pp. $826-840$

Athanasios D. Koustelios, (2001),"Personal characteristics and job satisfaction of Greek teachers", International Journal of Educational Management, Vol. 15 Iss: 7 pp. $354-358$

Bartunek, J.M. and Spreitzer, G.M. (2006), "The interdisciplinary career of a popular construct used in management- empowerment in the late 20th century",Journal of Management Inquiry, Vol. 15, pp. 255-73.

Baruch, Y. (1998), "Empowerment models in organizations", Career Development International, Vol. 3 No. 2, pp. 82-7.

Bowen, D. and Lawler, E.E. (1992), “The empowerment of service workers: what, why, how, and when",Sloan Management Review, Vol. 33 No. 3, pp. 31-9.

Brewer, E.W., Lim, D.H. and Cross, M.E. (2008), "Job satisfaction and employee 
perception of the learning environment in the health care management industry", Journal of Leadership Studies, Vol. 1 No. 4, pp. 37-50.

C, Dog us, Universitesi Dergisi, Vol. 9 No. 1, pp. 35-46.

Carless, S.A. (2004), "Does psychological empowerment mediate the relationship between psychological climate and job satisfaction?”, Journal of Business and Psychology, Vol. 18 No. 4, pp. 405-25.

Caudron, S. (1995), “Create an empowering environment”, Personal Journal, Vol. 74, pp. 28-36.

Chebat, J.C. and Kollias, P. (2000), "The impact of empowerment on customer-contact employees' role in service organizations", Journal of Service Research, Vol. 3 No. 1, pp. 66-82.

Conger, J.A. and Kanungo, R.N. (1988), "The empowerment process: integrating theory and practice", Academy of Management Review, Vol. 13 No. 3, pp. 471-82.

Conrad, K.M., Conrad, K.J. and Parker, J.E. (1985), "Job satisfaction among occupational health nurses", Journal of Community Health Nursing, Vol. 2, pp. 161- 73.

Cranny, C.J., Smith, P.C. and Stone, E.F. (1992), Job Satisfaction: How People Feel about Their Jobs and How It Affects Their Performance, Lexington, New York, NY.

Cunningham, I., Hyman, J. and Baldry, C. (1996), "Empowerment: the power to do what?", Industrial Relations Journal, Vol. 27 No. 2, pp. 143-54.

Darrow, L.E. (1971), "Empirical test of the Herzberg two-factor theory of job satisfaction", unpublished doctoral dissertation, East Texas State University, Commerce, TX.

David , D. D., Martha, C. A., and Neil S.B. (2008),"Mentoring, supervisor support, and perceived organizational support: what matters most?", Leadership \& Organization Development Journal, Vol. 29 Iss: 3 pp. $235-247$.

Eccles, T. (1993), “The deceptive allure of empowerment”, Long Range Planning, Vol. 26, pp. 13-21.

Elbeyi P., Yüksel, Ö, and Yalçin, A. (2011),"The effects of employee empowerment on employee job satisfaction: A study on hotels in Turkey", International Journal of Contemporary Hospitality Management, Vol. 23 Iss: 6 pp. $784-802$.

Haas, M.R. (2010), "The double-edged swords of autonomy and external knowledge: analyzing team effectiveness in a multinational organization", The Academy of Management Journal, Vol. 53, pp. 989-1008.

Hales, C. and Klidas, A. (1998), "Empowerment in five-star hotels: choice, voice or rhetoric?", International Journal of Contemporary Hospitality Management, Vol. 10 No. 3, pp. 88-95. 


\section{Macrothink}

Journal of Public Administration and Governance ISSN 2161-7104 2013, Vol. 3, No. 3

Han, S.-S., Moon, S.J. and Yun, E.K. (2009), "Empowerment, job satisfaction, and organizational commitment: comparison of permanent and temporary nurses in Korea", Applied Nursing Research, Vol. 22, pp. 15-20.

Herzberg, F. (1968), Work and the Nature of Man, World Publishing, New York, NY.

Hoseong, J., and Beomjoon C. (2012),"The relationship between employee satisfaction and customer satisfaction", Journal of Services Marketing, Vol. 26 Iss: 5 pp. $332-341$.

Igalens, J. and Roussel, P. (1999), "A French comparative study of the relationships between compensation work motivation and job satisfaction of exempt and non-exempt employees", Working Paper No. 224(96- 24), LIRHE, Unicersite Toulouse I, Toulouse.

Janssen, O., Schoonebeek, G. and Looy, V.B. (1997), "Cognitions of empowerment: the link between participative management and employees' innovative behavior", Gedrad en Organisatie, Vol. 10 No. 4, pp. 175-94.

Jui, C.C., and Colin.S. (2008),"The impact of locus of control on job stress, job performance and job satisfaction in Taiwan", Leadership \& Organization Development Journal, Vol. 29 Iss: 7 pp. $572-582$

Karin F., and Birgit, S. (2007),"Work satisfaction, organizational commitment and withdrawal behaviors", Management Research News, Vol. 30 Iss: 10 pp. 708 - 723.

Kim, S. (2002), "Participative management and job satisfaction: lessons for management leadership", Public Administration Review, Vol. 62 No. 2, pp. 231-41.

Kuhlen, R.G. (1963), "Needs, perceived need satisfaction opportunities, and satisfaction with occupation”,Journal of Applied Psychology, Vol. XL VII No. 1, pp. 56-64.

Kuo, H.T., Yin, T.J.C. and Li, I.C. (2007), "Relationship between organizational empowerment and job satisfaction perceived by nursing assistant at long-term care facilities", Journal of Clinical Nursing, Vol. 17, pp. 3059-66.

Le'vy-Garboua, L. and Montmarquette, C. (2004), "Reported job satisfaction: what does it mean?", Journal of Socio-Economics, Vol. 33, pp. 135

Locke, E. (1976), "The nature and causes of job satisfaction", in Dunnette, M. (Ed.), Handbook of Industrial and Organizational Psychology, Rand McNally, Chicago, IL, pp. 1297-349.

Locke, E.A. (1991), "The motivation sequence, the motivation hub, and the motivation core", OrganizationalBehavior and Human Decision Processes, Vol. 50, pp. 288-99.

Michailova, S. (2002), "When common sense becomes uncommon: participation and empowerment in Russian companies with Western participation", Journal of World Business, Vol. 37, pp. 180-7.

Mosammod, M.P., M, M. N.K. (2011), "Factors Affecting Employee Job Satisfaction Of Pharmaceutical Sector", Australian Journal of Business and Management Research Vol.1 
No.9 [113-123].

Paula, S. (2006), "Effects of disposition on hospitality employee job satisfaction and commitment", International Journal of Contemporary Hospitality Management Vol. 18 No. 4, 2006 pp. 317-328.

Petty, G.C., Brewer, E.W. and Brown, B. (2005), "Job satisfaction among employees of a youth development organization", child and Youth Care Forum, Vol. 34 No. 1.

Rainey, H.G. (1997), Understanding and Managing Public Organizations, 2nd ed., Jossey-Bass, San Francisco,CA.

Robert, C., Probst, T.M., Martocchio, J.J., Drasgow, F. and Lawler, J.J. (2000), "Empowerment and continuous improvement in the United States, Mexico, Poland, and India: predicting fit on the basis of the dimensions of power distance and individualism", Journal of Applied Psychology, Vol. 85, pp. 643-58.

Sigler, T.H. and Pearson, C.M. (2000), "Creating an empowering culture: examining the relationship beInternational Journal of Management Sciences and Business Research Volume 2, Issue 1- ISSN (2226-8235)tween organizational culture and perceptions of empowerment", Journal of Quality Management, Vol. 5, pp. 27-52.

Specter, P. (1997), Satisfaction: Application, Assessment, Causes and Consequences, Sage, London.

Spreitzer, G.M. and Mishra, A.K. (2002), "To stay or to go? Voluntary survivor turnover following on organizational downsizing”, Journal of Organizational Behavior, No. 23, pp. 707-29.

Spreitzer, G.M., De Janasz, S.C. and Quinn, R.E. (1999b), "Empowered to lead: the role of psychologicalempowerment in leadership”, Journal of Organizational Behavior, Vol. 20, pp. 511-26.

Sut, I. W.h., and Chad, P. (2011),"Employee empowerment, job satisfaction and organizational commitment: An in-depth empirical investigation", Chinese Management Studies, Vol. 5 Iss: 3 pp. $325-344$.

Sweeney, A., Hohenshil, T. and Fortune, J. (2002), "Job satisfaction among employee assistance professionals”,Journal of Employment Counselling, Vol. 39, pp. 52-60

Theo J.M., and van d.V., (2004),"Productivity and employee satisfaction in flexible workplaces", Journal of Corporate Real Estate, Vol. 6 Iss: 2 pp. 133 - 148.

Therese, A. J., and Steve, B. (2006), "The antecedents of organizational commitment: the case of Australian casual academics", International Journal of Educational Management Vol. 20 No. 6, 2006 pp. 439-452.

Thomas, K.W. and Velthouse, B.S. (1990), "Cognitive elements of empowerment", Academy of Management Review, Vol. 15 No. 4, pp. 666-81. 


\section{Macrothink}

Ulker, C., Osman, C., and Hakan, A. (2010), "The Effects Of Perceived Organizational Support On Employees' Affective Outcomes: Evidence From The Hotel Industry”, Tourism and Hospitality Management, Vol. 16, No. 2, pp. 125-150, 2010.

Wilkinson, A. (1998), "Empowerment: theory and practice", Personnel Review, Vol. 27, pp. 40-56. 